\title{
Plasmid-mediated Chloramphenicol Resistance in Staphylococcus hyicus
}

\author{
By STEFAN SCHWARZ, * MARISA CARDOSO AND HANS BLOBEL \\ Institut für Bakteriologie und Immunologie der Justus-Liebig Universität Giessen, \\ Frankfurterstr. 107, 6300 Giessen, FRG
}

(Received 26 June 1989; revised 31 August 1989; accepted 12 September 1989)

\begin{abstract}
A small plasmid of $3.95 \mathrm{~kb}$, encoding resistance to chloramphenicol $(\mathrm{Cm})$ was detected in three of 33 Staphylococcus hyicus strains. The plasmid in each of the three strains was indistinguishable by Southern-blot hybridization and restriction enzyme analysis. It was shown by curing and by transformation to specify resistance to $\mathrm{Cm}$. A preliminary restriction map of the plasmid, designated pSC2, is presented. Chloramphenicol acetyltransferase was demonstrated by enzyme assay and by SDS-PAGE of cell-free lysates of pSC 2 transformants.
\end{abstract}

\section{INTRODUCTION}

Staphylococci are frequently isolated from skin infections of domestic animals. In pigs, Staphylococcus hyicus causes exudative epidermitis, which affects mainly suckling piglets and is often promoted by abrasions of the skin due to scratches, bites, rough bedding or ectoparasites (Eich, 1985; Gyles \& Thoen, 1986; Rolle \& Mayr, 1984). Exudative epidermitis causes great economic losses by retarding the growth of the piglets (Eich, 1985). Antibiotics are commonly used to control this infection (Eich, 1985; Rolle \& Mayr, 1984), but the staphylococci are often resistant to antibiotics. The existence of plasmids in $S$. hyicus has been reported (Kloos et al., 1981; Noble et al., 1988; Schwarz \& Blobel, 1989), but a causal relationship to antimicrobial resistance could not be definitely determined (Kloos et al., 1981; Schleifer, 1986). Therefore, further studies were made of the antimicrobial resistance and plasmid content of $S$. hyicus strains isolated from piglets suffering from exudative epidermitis, with particular reference to their chloramphenicol resistance.

\section{METHODS}

Bacterial strains. A total of 33 strains of $S$. hyicus isolated from pigs with exudative epidermitis from different farms in several geographical areas of Germany between 1983 and 1986 were used. Most of the strains were provided by G. Amtsberg, Institut für Mikrobiologie und Tierseuchen, Hannover, FRG. The $S$. hyicus reference strain NCTC 10350 was included. All strains were identified according to Schleifer (1986).

Growth conditions and culture media. Stock cultures of $S$. hyicus were prepared by overnight incubation at $37^{\circ} \mathrm{C}$ on sheep blood agar (blood agar base, Gibco, supplemented with $5 \%$, v/v, sheep blood) and subsequent storage at $4{ }^{\circ} \mathrm{C}$. Single colonies from these stock culture plates were inoculated into brain heart infusion broth (BHI, Merck) and grown for $18 \mathrm{~h}$ at $37^{\circ} \mathrm{C}$ on a rotary shaker (75 r.p.m.) for plasmid isolation, antibiograms and chloramphenicol acetyltransferase assays. Antibiograms were obtained from ASS-agar plates (Merck). In curing experiments Trypticase-Soy-Agar plates (TSA, Oxoid) were used, and for protoplast transformation experiments osmotically stable media were prepared as described by Chang \& Cohen (1979).

Plasmid isolation. For large-scale preparation of plasmid DNA, the three relevant $S$. hyicus strains were subjected to a modification of the alkaline lysis procedure of Maniatis et al. (1982). After overnight incubation in $500 \mathrm{ml} \mathrm{BHI}$, containing $15 \mu \mathrm{g}$ chloramphenicol $\mathrm{ml}^{-1}$, the staphylococci were harvested by centrifugation for $10 \mathrm{~min}$ at $6000 \mathrm{~g}$. Each pellet was resuspended in $10 \mathrm{ml}$ glucose-TE buffer $(50 \mathrm{~mm}$-glucose, $25 \mathrm{~mm}-\mathrm{Tris} / \mathrm{HCl}$, $10 \mathrm{~mm}$-EDTA, pH 8.0), supplemented with $40 \mu \mathrm{g}$ lysostaphin $\mathrm{ml}^{-1}$ (Sigma). After $2 \mathrm{~h}$ incubation at $37^{\circ} \mathrm{C}, 20 \mathrm{ml}$ alkaline lysis solution, consisting of $1 \%(\mathrm{w} / \mathrm{v})$ sodium dodecyl sulphate (SDS) in $0.2 \mathrm{M}-\mathrm{NaOH}$, was carefully added.

Abbreviations: CAT, chloramphenicol acetyltransferase; $\mathrm{Cm}$, chloramphenicol. 
The suspension was stored on ice for $5 \mathrm{~min}$, neutralized by the addition of $15 \mathrm{ml} 3 \mathrm{M}$ sodium acetate $\mathrm{pH} 4.8$ and kept on ice for $1 \mathrm{~h}$. The cell debris was then pelleted by centrifugation for $15 \mathrm{~min}$ at $6000 \mathrm{~g}$ and the plasmidcontaining supernatant mixed with 2.5 vols ice-cold ethanol. The mixture was stored for $2 \mathrm{~h}$ at $-70^{\circ} \mathrm{C}$ to precipitate plasmid DNA, which was then sedimented by centrifugation for $15 \mathrm{~min}$ at $6000 \mathrm{~g}$. The supernatant was discarded. The sedimented plasmids were dried, resuspended in $3 \mathrm{ml}$ TE- $\mathrm{CsCl}$ buffer $(5 \cdot 3 \mathrm{~g} \mathrm{CsCl}$ per $5 \mathrm{ml} \mathrm{TE}-$ buffer), and $60 \mu \mathrm{l}$ of an aqueous solution of ethidium bromide $\left(8 \mathrm{mg} \mathrm{ml}^{-1}\right)$ was added. The plasmids were purified by density-gradient centrifugation for $16 \mathrm{~h}$ at $175000 \mathrm{~g}$. Finally, the plasmid suspension was washed three times with an equal volume of butanol to remove ethidium bromide, dialysed for $20 \mathrm{~h}$ against $10 \mathrm{mM}-\mathrm{Tris} / \mathrm{HCl} \mathrm{pH} 8.0$ and stored at $-20^{\circ} \mathrm{C}$. This protocol was used to isolate plasmid DNA for transformation experiments and restriction enzyme analysis. Small-scale preparation of plasmids, used for screening transformants and cured clones, was carried out as previously described (Schwarz et al., 1989a,b).

Antibiograms. Antimicrobial resistance patterns of all $S$. hyicus strains were obtained by the agar diffusion method (Barry \& Thornsberry, 1985). Discs containing, respectively, $25 \mu \mathrm{g}$ ampicillin, $30 \mu \mathrm{g}$ cephalothin, $30 \mu \mathrm{g}$ chloramphenicol, $10 \mu \mathrm{g}$ clindamycin. $15 \mu \mathrm{g}$ erythromycin, $10 \mu \mathrm{g}$ gentamicin, $30 \mu \mathrm{g}$ kanamycin, $100 \mu \mathrm{g}$ nitrofurantoin, $10 \mu \mathrm{g}$ streptomycin, $30 \mu \mathrm{g}$ tetracycline or $1.25 \mu \mathrm{g}$ trimethoprim plus $23.75 \mu \mathrm{g}$ sulfamethoxazole (Oxoid) were used. The antibiograms were evaluated after incubation for $18-24 \mathrm{~h}$ at $37^{\circ} \mathrm{C}$ (Barry \& Thornsberry, 1985).

Curing. Single colonies of the $S$. hyicus strains were incubated for $48-72 \mathrm{~h}$ at $42^{\circ} \mathrm{C}$ in $\mathrm{BHI}$, supplemented with $15 \mu \mathrm{g}$ ethidium bromide $\mathrm{ml}^{-1}$. The bacteria were then inoculated onto TSA plates and, after overnight incubation at $37^{\circ} \mathrm{C}$, replica-plated onto selective TSA plates, containing $15 \mu \mathrm{g}$ chloramphenicol $\mathrm{ml}^{-1}$. Clones that appeared to be 'cured' were screened for plasmid content.

Plasmid transformation procedure. A modification of the method of Chang \& Cohen (1979) was applied for the transfer of the $S$. hyicus plasmids. Staphylococcus aureus RN4220, a derivative of $S$. aureus 8325 (Novick, 1967), served as a recipient. Two millilitres of an overnight culture of $S$. aureus RN4220 were added to $48 \mathrm{ml}$ BHI and incubated on a rotary shaker at $37^{\circ} \mathrm{C}$ until the culture reached an $\mathrm{OD}_{600}$ of 0.8 . The staphylococci were then harvested by centrifugation for $10 \mathrm{~min}$ at $5000 \mathrm{~g}$ and resuspended in $5 \mathrm{ml} \mathrm{SMMP-buffer} \mathrm{(Chang} \mathrm{\&} \mathrm{Cohen,} \mathrm{1979).}$ Lysostaphin was added to a final concentration of $40 \mu \mathrm{g} \mathrm{ml} \mathrm{m}^{-1}$, followed by incubation for $2 \mathrm{~h}$ at $37^{\circ} \mathrm{C}$. The protoplasts were pelleted $\left(10 \mathrm{~min}, 5000 \mathrm{~g}, 15^{\circ} \mathrm{C}\right)$ and resuspended in $5 \mathrm{ml} \mathrm{SMMP-buffer}$. Transformation was carried out by mixing $500 \mu \mathrm{l}$ of the protoplast suspension with $10-50 \mu \mathrm{l}$ of a plasmid suspension, containing 1-5 $\mathrm{gg}$ DNA. Then $1.5 \mathrm{ml}$ of a filter sterilized $40 \%(\mathrm{w} / \mathrm{v})$ polyethylene glycol solution (PEG; approx. $M_{\mathrm{r}} 6000$, Sigma) was added. After $2 \mathrm{~min}$ of gentle shaking, $5 \mathrm{ml}$ SMMP-buffer was added and the protoplasts centrifuged again for $10 \mathrm{~min}$ at $5000 \mathrm{~g}$. Each pellet was resuspended in $1 \mathrm{ml} \mathrm{SMMP-buffer} \mathrm{and} \mathrm{incubated} \mathrm{for} 2 \mathrm{~h}$ at $37^{\circ} \mathrm{C}$ to allow phenotypic expression. Then $100 \mu$ l volumes of the protoplast suspension were applied to DM3-regeneration plates (Chang \& Cohen, 1979), supplemented with $15 \mu \mathrm{g}$ chloramphenicol ml${ }^{-1}$. Transformants appeared after 48-72 $\mathrm{h}$ at $37^{\circ} \mathrm{C}$. SMMP-buffer was used instead of the plasmid suspension as a control. A previously described chloramphenicol resistance $\left(\mathrm{Cm}^{\mathrm{R}}\right)$ plasmid from Staphylococcus intermedius (Schwarz et al., 1989a) served as a positive control.

Restriction endonuclease analysis. Restriction enzyme digestions with the endonucleases $A c c \mathrm{I}, B a m \mathrm{HI}, B g l \mathrm{II}$, Bst EII, ClaI, EcoRI, HaeIII, HindIII, HpaII, KpnI, PvuII, MboI and TaqI (Boehringer Mannheim) were carried out (Schwarz et al., 1989b). Mapping of the different cleavage sites was performed by double-enzyme digestions. The sizes of the DNA fragments were determined by electrophoresis in $0.7-2.0 \%(\mathrm{w} / \mathrm{v})$ agarose gels; electrophoresis was conducted for $3 \mathrm{~h}$ at $6 \mathrm{~V} \mathrm{~cm}^{-1}$ in Tris/acetate buffer, $\mathrm{pH} 7.8$ (Maniatis et al., 1982). Very small DNA fragments $(50-300 \mathrm{bp})$ were analysed in $8 \%(\mathrm{w} / \mathrm{v})$ polyacrylamide gels using Tris/borate buffer $\mathrm{pH} 8.0$ (Maniatis et al., 1982); these gels were run for $5 \mathrm{~h}$ at $10 \mathrm{~V} \mathrm{~cm}^{-1}$. Both agarose and polyacrylamide gels were stained with ethidium bromide $\left(10 \mu \mathrm{g} \mathrm{m}^{-1}\right)$. The plasmid DNA was visualized by UV-illumination. Photographs were taken on Polaroid type $667 \mathrm{film}$. The sizes of the plasmid fragments were deduced from logarithmic plots by comparison with marker DNA which consisted of HaelII-digested $\lambda$ dv1 DNA (Kröger et al., 1984) and PB1 DNA cleaved separately with PstI (5664 bp), HindIII (4133, 845, 686 bp) and PstI/BamHI (3136, 2528 bp).

Southern blot hybridization. This was performed as a capillary blot procedure (Gene Screen Plus catalog N.NEF 976, 1985), using a 'Gene Screen Plus' hybridization transfer membrane (DuPont). Prehybridization, radioactive labelling and hybridization were carried out as previously described (Schwarz et al., 1989 b). The $\mathrm{Cm}^{\mathrm{R}}$ plasmid of $S$. hyicus reisolated from a transformed $S$. aureus clone, served as a probe.

Bioassay for the enzymic inactivation of chloramphenicol. A modification of the method of Burns et al. (1985) was used to demonstrate enzymic inactivation of $\mathrm{Cm}$. A lawn of chloramphenicol-sensitive $S$. aureus RN4220 was streaked on an ASS plate. Discs $9 \mathrm{~mm}$ in diameter were cut of Whatman no. 1 filter paper, and inoculated with $20 \mu$ l suspensions of each chloramphenicol-resistant $S$. hyicus strain and a representative chloramphenicolresistant $S$. aureus RN4220 transformant. The original, plasmidless $S$. aureus RN4220 served as a negative control and a chloramphenicol-resistant $S$. intermedius strain as a positive control. Then a disc containing $30 \mu \mathrm{g}$ chloramphenicol was placed in the middle of the inoculated filter paper. After overnight incubation at $37^{\circ} \mathrm{C}$ the zones of inhibition were measured. If the $\mathrm{Cm}$ passed in its active form through the filter paper, the growth of the 
susceptible $S$. aureus RN4220 would be inhibited. No, or significantly reduced, inhibition would be observed if the $\mathrm{Cm}$ was inactivated by the bacteria on the filter paper.

Rapid chloramphenicol acetyltransferase (CAT) assay. The method of Azemun et al. (1981) was modified to demonstrate CAT activity in the original chloramphenicol-resistant $S$. hyicus strains and their $S$. aureus RN4220 transformants. The original chloramphenicol-sensitive $S$. aureus RN4220 was used as negative control. The cultures were grown overnight at $37^{\circ} \mathrm{C}$ in $2 \mathrm{ml} \mathrm{BHI}$ and harvested by centrifugation for $10 \mathrm{~min}$ at $5000 \mathrm{~g}$ in $1.5 \mathrm{ml}$ reaction cups (Eppendorf). Each pellet was resuspended in $200 \mu \mathrm{l}$ of a buffer containing $1 \mathrm{M}-\mathrm{NaCl}$ and $0.01 \mathrm{M}$ EDTA pH 8.0. Lysostaphin was added to a final concentration of $40 \mu \mathrm{g} \mathrm{ml}^{-1}$ and the suspension was incubated for $30 \mathrm{~min}$ at $37^{\circ} \mathrm{C}$. Duplicate tubes were prepared of each culture with $100 \mu \mathrm{m} \mathrm{m}$-Tris/ $\mathrm{HCl} \mathrm{pH} 8.0$ or $100 \mu \mathrm{l} 5 \mathrm{~m}-$ acetyl coenzyme A (Boehringer Mannheim). Then $200 \mu \mathrm{l} 5 \mathrm{~mm}-\mathrm{Cm}$ was pipetted into each assay tube and the same volume of distilled water into the control tubes. Finally, $20 \mu \mathrm{l} 0 \cdot 2 \mathrm{~mm}-5,5^{\prime}$-dithiobis-(2-nitrobenzoic acid) (DTNB, Sigma) in $0.1 \mathrm{M}$-Tris/ $\mathrm{HCl} \mathrm{pH} 8.0$ was added to all tubes. After $5 \mathrm{~min}$ at $37^{\circ} \mathrm{C}$, the colour in each assay tube was compared with that in the respective control tube.

Detection of $C A T$. (a) Induction of CAT. The expression of all known CAT variants from staphylococci is inducible by $\mathrm{Cm}$ or certain analogues. However, $\mathrm{Cm}$ itself serves as substrate for this enzyme. This leads, depending on the basal CAT activity, to a rapid inactivation of the inducer by acetylation and consequently to reduced induction rates. In order to optimize CAT induction, acetylated $\mathrm{Cm}$ must be replaced by fresh $\mathrm{Cm}$. Therefore $\mathrm{Cm}$ was added to a final subinhibitory concentration of $75 \mu \mathrm{g} \mathrm{ml}^{-1}$ after each doubling of the bacteria. This was estimated by turbidity measurements (Shaw, 1975). Thus, pSC 2 transformants were grown in $50 \mathrm{ml}$ BHI to $\mathrm{OD}_{600} 0.65$ (mid-exponential phase). After a final addition of $\mathrm{Cm}$, the staphylococci were allowed to grow for another 30-60 min at $37^{\circ} \mathrm{C}$, to enable maximum CAT induction before harvest (Shaw, 1975). For determinations of the basal level of CAT expression without induction, pSC2 transformants were treated in the same manner, except that the medium was not supplemented with $\mathrm{Cm}$. As a negative control, untransformed $S$. aureus $\mathrm{RN} 4220$ was grown under the same conditions, but also without $\mathrm{Cm}$.

(b) Preparation of cell-free extracts. Harvested cells of transformed and untransformed $S$. aureus RN4220 were washed with $5 \mathrm{ml}$ of buffer containing $0.05 \mathrm{M}-\mathrm{Tris} / \mathrm{HCl}$ and $0.15 \mathrm{M}-\mathrm{NaCl}, \mathrm{pH} 7.5$. The bacteria were pelleted and resuspended in $1 \mathrm{ml}$ of the same buffer, Then $40 \mu \mathrm{l}$ lysostaphin $\left(2 \mathrm{mg} \mathrm{ml}^{-1}\right)$ was added. After $15 \mathrm{~min}$ at $37^{\circ} \mathrm{C}, 20 \mu \mathrm{l}$ deoxyribonuclease ( $1 \mathrm{mg} \mathrm{ml}^{-1}$, Boehringer Mannheim) was added, followed by another $15 \mathrm{~min}$ incubation at $37^{\circ} \mathrm{C}$. The cell debris was pelleted by centrifugatiom for $20 \mathrm{~min}$ at $15000 \mathrm{~g}$ and the clear supernatant used for SDSPAGE.

(c) SDS-PAGE. Twenty microlitres of the clear supernatant were mixed with $50 \mu l$ loading buffer, heated for $10 \mathrm{~min}$ at $100{ }^{\circ} \mathrm{C}$ and analysed in $11 \%(\mathrm{w} / \mathrm{v})$ polyacrylamide gels (Maniatis et al., 1982). Electrophoresis was carried out for $6 \mathrm{~h}$ at $10 \mathrm{~V} \mathrm{~cm}^{-1}$. Coomassie brilliant blue was used to stain the gels. SDS-7-marker (Sigma), containing trypsin inhibitor from soybean $\left(M_{\mathrm{r}} 20100\right)$, trypsinogen (PMSF treated) (24000), carbonic anhydrase from bovine erythrocytes (29000), glutaraldehyde-3-phosphate dehydrogenase from rabbit muscle $(36000)$, albumin from egg (45000), and bovine serum albumin (66000), served as standards.

\section{RESULTS}

\section{Plasmid content and chloramphenicol resistance}

$\mathrm{Cm}^{\mathrm{R}}$ occurred in only three of the 22 plasmid-positive and in none of the 11 plasmid-negative $S$. hyicus strains. Although these three chloramphenicol-resistant strains were not related epidemiologically, they exhibited a common plasmid band in agarose gel electrophoresis (Fig. 1, lanes $1,3,5$ ), which was not detectable in the plasmid profiles of the remaining 19 plasmidcontaining $S$. hyicus strains.

\section{Curing and protoplast transformation}

In curing experiments, clones were obtained from all three strains which had become sensitive to $\mathrm{Cm}$ and lost all their plasmids. For the interspecific transformation of protoplasts of $S$. aureus RN4220 the complete plasmid content of the three chloramphenicol-resistant $S$. hyicus strains was used. In all three cases chloramphenicol-resistant $S$. aureus RN4220 transformants were obtained. Fifteen clones from each of the three transformations were analysed for plasmid content. All of them contained a small plasmid of the same size as that in the $S$. hyicus strains (Fig. 1, lanes 2, 4, 6). 


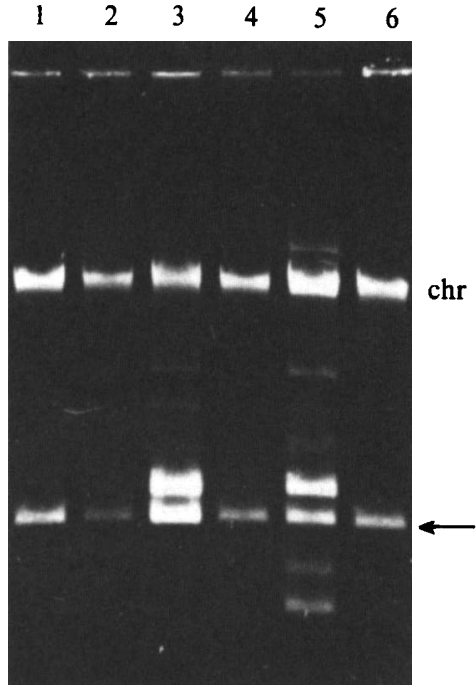

Fig. 1

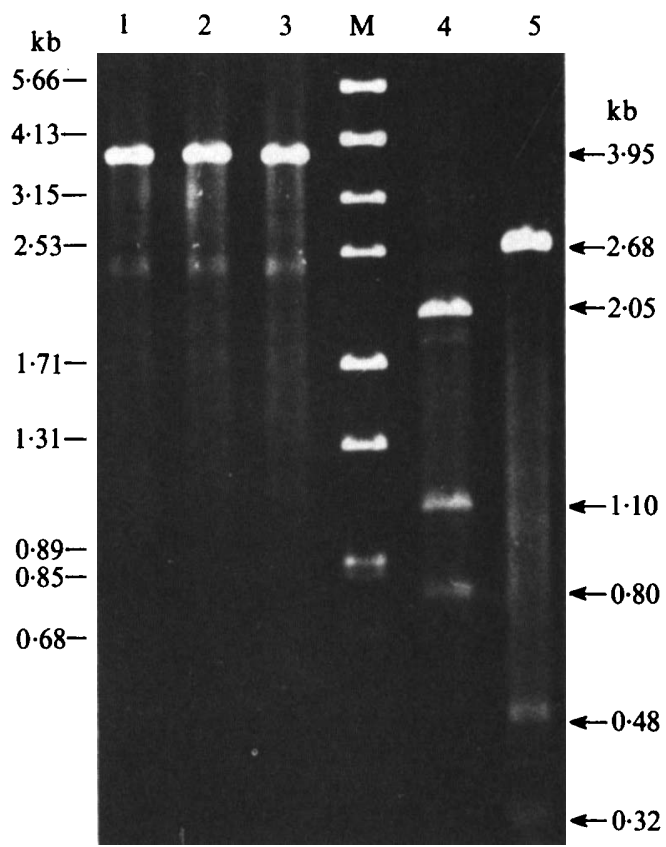

Fig. 2

Fig. 1. Agarose gel electrophoresis of uncleaved plasmids of the three chloramphenicol-resistant $S$. hyicus strains (lanes $1,3,5$ ) and their respective chloramphenicol-resistant $S$. aureus RN4220 transformants (lanes $2,4,6$ ). The presumptive $\mathrm{Cm}^{\mathrm{R}}$ plasmid is marked with an arrow; chr, chromosomal DNA.

Fig. 2. Agarose gel electrophoresis of single restriction enzyme digests of the $\mathrm{Cm}^{\mathrm{R}}$ plasmid $\mathrm{pSC} 2$ from $S$. hyicus. Sizes of the marker DNA are shown on the left, sizes of the plasmid fragments on the right. Lanes: 1, pSC2 cleaved with $A c c \mathrm{I} ; 2$, pSC2 cleaved with BstEII; 3, pSC2 cleaved with HpaII; M, PB1/ $\lambda \mathrm{dv1}$ marker DNA; 4, pSC2 cleaved with $M$ boI; 5, pSC2 cleaved with TaqI (this yielded six fragments; only the three largest fragments are visible).

\section{Restriction endonuclease analysis}

The plasmids of the chloramphenicol-resistant transformants were compared on the basis of restriction enzyme digests. For this we used the following endonucleases, known to cleave $\mathrm{Cm}^{\mathrm{R}}$ plasmids of $S$. aureus or $S$. intermedius (Gillespie \& Skurray, 1988; Schwarz et al., 1989a): AccI, BamHI, BglII, BstEII, ClaI, EcoRI, HaeIII, HindIII, HpaII, KpnI, PvuII, MboI and TaqI. The transformed $\mathrm{Cm}^{\mathrm{R}}$ plasmids of the three $S$. hyicus strains had the same distribution of restriction endonuclease cleavage sites. None of them had recognition sites for BamHI, ClaI, EcoRI, HaeIII, HindIII, KpnI or PvuII. In all cases linearization was achieved with AccI, BstEII and HpaII (Fig. 2). The linear plasmid was approximately $3.95 \mathrm{~kb}$ in size. Digestion with $M b o \mathrm{I}$ resulted in three fragments, of $2.05,1.10$ and $0.80 \mathrm{~kb}$. TaqI cleaved the plasmid into six fragments, of 2.68, 0.48, 0.32, 0.30, $0 \cdot 11$ and $0.05 \mathrm{~kb}$. A preliminary restriction enzyme map of the $\mathrm{Cm}^{\mathrm{R}}$ plasmid from $S$. hyicus, designated $\mathrm{pSC}$, was constructed by double restriction enzyme digests. This restriction map was used to compare pSC2 with other staphylococcal $\mathrm{Cm}^{\mathrm{R}}$ plasmids such as pC223, pC194, pC221 and pUB112 (Fig. 3). A high degree of conformity between $\mathrm{pSC} 2, \mathrm{pC} 221$ and pUB112 was found in the regions which encoded the resistance mechanism and replication functions in the latter two plasmids. In contrast, there were only minor structural relationships between $\mathrm{pSC} 2$ and $\mathrm{pC} 223$ or pC194. 

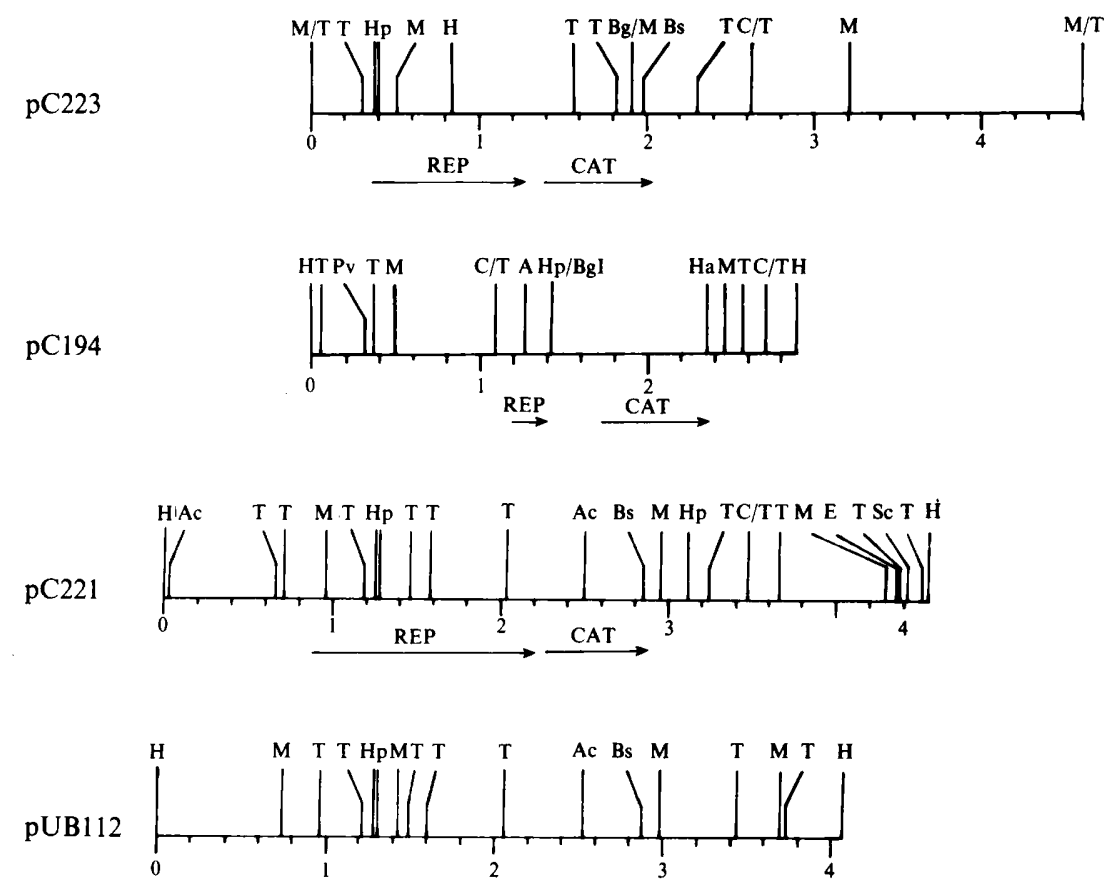

$\mathrm{pSC} 2$

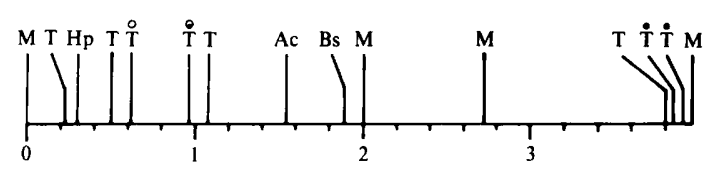

Fig. 3. Restriction maps of the staphylococcal $\mathrm{Cm}^{\mathrm{R}}$ plasmids pC223 (Novick, 1976), pC194 (Horinouchi \& Weisblum, 1982), pC221 (Brenner \& Shaw, 1985), pUB112 (Brückner et al., 1984) and pSC2. Restriction enzyme cleavage sites are: Ac, AccI; BgI, BglI; Bg, BglII; Bs, BstEII; C, ClaI; E, EcoRI; Ha, HaeIII; H, HindIII; Hp, HpaII; M, MboI; Pv, PvuII; Sc, SacI; T, TaqI. Scales (kb) are shown below each map; regions encoding replication functions (REP) and chloramphenicol acetyltransferase (CAT) are indicated below the maps of pC223, pC194 and pC221 (the arrows indicate the direction of transcription of the REP- and CAT genes). In pSC2, the correct positions of the $\mathrm{T}$ - and $\dot{T}$-cleavage sites could not be determined exactly; the two possible positions of each are both marked.

\section{Southern blot hybridization}

The $\mathrm{Cm}^{\mathrm{R}}$ plasmid, reisolated from a transformed clone and radioactively labelled, served as a probe for Southern blot hybridization. The probe specifically recognized the respective $\mathrm{Cm}^{\mathrm{R}}$ plasmid of the three $S$. hyicus strains, leading to identical hybridization patterns (Fig. 4). The additional plasmids occurring in two of the three $S$. hyicus strains were not recognized,. The upper signals visible in the autoradiograph are due to open circular forms of $\mathrm{pSC} 2$ which, because of their small quantities, are not visible in the less sensitive ethidium-bromide-stained agarose gel.

\section{Mechanism of chloramphenicol resistance}

In the modified bioassay the three chloramphenicol-resistant $S$. hyicus strains, a representative chloramphenicol-resistant $S$. aureus RN4220 transformant and the chloramphenicol-resistant $S$. intermedius-strain differed significantly from the chloramphenicolsensitive $S$. aureus RN4220. All the chloramphenicol-resistant staphylococcal strains inactivated $\mathrm{Cm}$, abolishing its inhibitory effects on the growth of the chloramphenicol-sensitive $S$. aureus RN4220. The chloramphenicol-sensitive $S$. aureus RN4220 did not inactivate $\mathrm{Cm}$. 


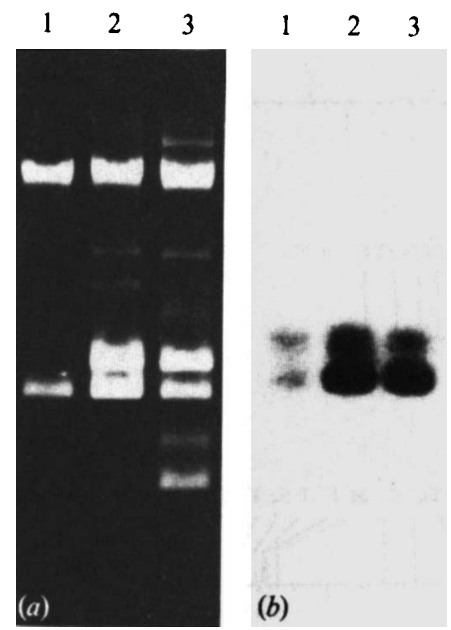

Fig. 4

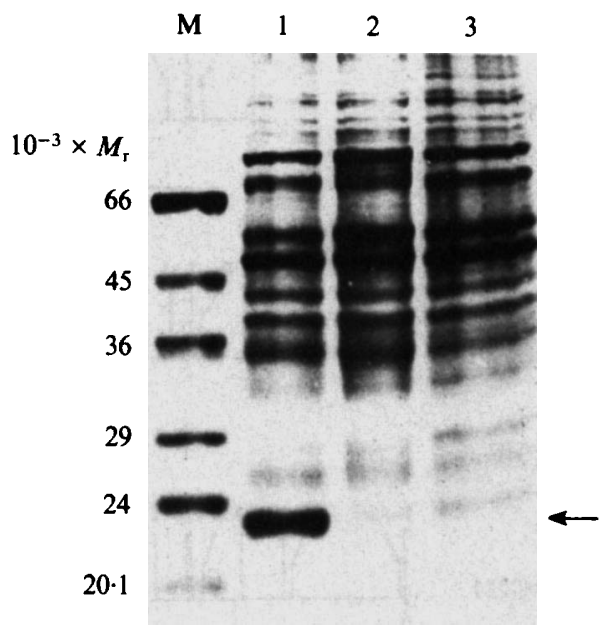

Fig. 5

Fig. 4. Southern blot hybridization. (a) Agarose gel, stained with ethidium bromide, showing the plasmid content of the three chloramphenicol-resistant $S$. hyicus strains; (b) autoradiography of the gel after hybridization with labelled $\mathrm{Cm}^{\mathrm{r}}$ plasmid isolated from a transformed clone of $S$. aureus RN4220.

Fig. 5. Coomassie-blue-stained gel following SDS-PAGE of cell-free lysates of a Cm-induced pSC2 transformant of $S$. aureus RN4220 (lane 1), the original chloramphenicol-sensitive $S$. aureus RN4220 (lane 2) and an uninduced pSC2 transformant (lane 3). The presumptive CAT band is marked by an arrow. $\mathbf{M}$, marker proteins.

All the chloramphenicol-resistant $S$. hyicus strains, and their chloramphenicol-resistant $S$. aureus RN4220 transformants, produced CAT, as determined in the rapid CAT assay, but CAT activity was not detectable in the original chloramphenicol-sensitive $S$. aureus RN4220. Furthermore, CAT could also be demonstrated by SDS-PAGE in cell-free extracts from the chloramphenicol-resistant transformants, but not in extracts from the original chloramphenicolsensitive $S$. aureus RN4220. The presumptive CAT band appeared in SDS-PAGE with an $M_{\mathrm{r}}$ of approximately $23000 \mathrm{Da}$ (Fig. 5). Great differences in the level of CAT expression were observed between uninduced and $\mathrm{Cm}$-induced pSC2 transformants, suggesting that the CAT of pSC2 was an inducible enzyme.

\section{DISCUSSION}

Plasmids as carriers of resistance genes in staphylococci have long been known (Lyon \& Skurray, 1987). For $S$. hyicus, plasmids and antimicrobial resistance patterns have also been reported (Kloos et al., 1981; Noble et al., 1988; Schwarz \& Blobel, 1989). However, a causal relationship between these plasmids and specific resistance patterns had not been established (Kloos et al., 1981 ; Schleifer, 1986). First attempts to identify antimicrobial resistance plasmids in $S$. hyicus by Noble et al. (1988) involved solely curing experiments. A plasmid encoding resistance to $\mathrm{Cm}$ could not be detected by this method. Furthermore, curing experiments alone might result in misleading information, particularly if the "cured' derivative had lost two or more plasmids. Therefore, in addition to curing experiments we conducted the more specific protoplast transformations. Both procedures proved the extrachromosomal nature of $\mathrm{Cm}^{\mathrm{R}}$ in the three $S$. hyicus strains and enabled us to identify a $3.95 \mathrm{~kb}$ plasmid, designated pSC2 as being responsible for this resistance. Moreover, the protoplast transformations resulted in transformants which carried only the plasmid encoding $\mathrm{Cm}^{\mathrm{R}}$ and none of the other plasmids of the original $S$. hyicus strains. Thus, the $\mathrm{Cm}^{\mathrm{R}}$ plasmid of the transformants proved suitable for further characterization by restriction endonuclease analysis. For this purpose enzymes were 
chosen which had cleavage sites in the $\mathrm{Cm}^{\mathrm{R}}$ plasmids of 'human' $S$. aureus and 'canine' $S$. intermedius cultures (Gillespie \& Skurray, 1988; Schwarz et al., 1989a). The restriction analyses resulted in the construction of a preliminary restriction map of $\mathrm{pSC} 2$, which was used as a basis for the comparison of $\mathrm{pSC} 2$ with other staphylococcal $\mathrm{Cm}^{\mathrm{R}}$ plasmids.

In staphylococci, three distinct families of $\mathrm{Cm}^{\mathrm{R}}$ plasmids have been identified on the basis of restriction endonuclease cleavage sites and sequence analyses of their CAT genes. The prototype $\mathrm{Cm}^{\mathrm{R}}$ plasmids of these families are pC223, pC194 and pC221 (Gillespie \& Skurray, 1988). The $S$. hyicus $\mathrm{Cm}^{\mathrm{R}}$ plasmid pSC2 appears to be closely related to the members of the pC221 family. The criterion for classification of pSC2 in this plasmid family is the similarity of the restriction maps in the region of the REP (plasmid replication) and CAT genes. Members of the pC221 family have been isolated during the last 35 years (Gillespie \& Skurray, 1988) from several staphylococcal species of human and animal origin in different geographical areas. A possible reason for the 'in toto'-spread of this highly conserved REP/CAT region could be the existence of specific sequences flanking the REP/CAT region and enabling recombinational events to occur (Gillespie \& Skurray, 1988). Such a recombination site was mapped in the nucleotide sequence of pC221 (Novick et al., 1984). In contrast to other observations (Lacey, 1980), the occurrence of this REP/CAT gene region in 'human' $S$. aureus and 'porcine' $S$. hyicus cultures also confirmed the in vivo gene transfer between different staphylococcal species from infections of humans and animals. Furthermore, the presence of homologous CAT regions indicates that the members of the pC221 family share a common resistance mechanism, namely the enzymic inactivation of $\mathrm{Cm}$ (Shaw \& Brodsky, 1988) by the same CAT variant. This enzyme catalyses the transfer of acetyl groups from acetyl-CoA to $\mathrm{Cm}$, resulting in 3-acetyl and 1,3diacetyl derivatives (Shaw, 1967). These acetylated $\mathrm{Cm}$ derivatives are devoid of antibiotic activity (Shaw \& Unowsky, 1968) and also of the ability to induce CAT gene expression (Brückner \& Matzura, 1985). In contrast to enterobacteria, which produce CAT constitutively (Fitton et al., 1978), CAT expression in staphylococci has to be induced (Winshell \& Shaw, 1969) with $\mathrm{Cm}$ or its fluorinated derivatives (Brückner \& Matzura, 1985). The inducibility of CAT from $S$. hyicus encoded by $\mathrm{pSC}$, could also be demonstrated since there were great differences in the levels of CAT expression in uninduced and $\mathrm{Cm}$-induced $\mathrm{pSC} 2$ transformants. All $\mathrm{Cm}^{\mathrm{R}}$ plasmids of staphylococci that have been investigated carry the genetic information for the CAT monomer, a polypeptide of varying $M_{\mathrm{r}}$ in the range of 22500-26200 (Zaidenzaig et al., 1979; Horinouchi \& Weisblum, 1982). Formerly, native CAT was considered to be tetrameric (Shaw, 1975), but recently, X-ray crystallography revealed CAT to be a trimer of identical subunits with a distinct protein fold (Leslie et al., 1988). The $M_{\mathrm{r}}$ of a subunit of CAT from pSC2 was determined to be in the order of 23000 , according to its electrophoretic mobility in SDS-PAGE relative to that of the marker proteins. However, this size should be considered to be only approximate, because some CAT variants of staphylococci seem to migrate anomalously in SDS-PAGE, giving lower $M_{\mathrm{r}}$ values than expected from their amino acid sequences (Zaidenzaig et al., 1979).

The authors wish to thank Mrs S. Grölz-Krug and Mrs U. Neuschulz for their excellent technical assistance and Professor Dr G. Hobom for providing marker DNA.

\section{REFERENCES}

Azemun, P., Stull, T., Roberts, M. \& Smith, A. L. (1981). Rapid detection of chloramphenicol resistance in Haemophilus influenzae. Antimicrobial Agents and Chemotherapy 20, 168-170.

BARRY, A. L. \& THORNSBERRY, C. (1985). Susceptibility tests: diffusion test procedures. In Manual of Clinical Microbiology, 4th edn, pp. 978-987. Edited by E. H. Lenette, A. Balows, W. H. Hausler, Jr \& H. J. Shadomy, Washington, DC : American Society for Microbiology.
Brenner, D. G. \& SHaw, W. V. (1985). The use of synthetic oligonucleotides with the universal templates for rapid DNA sequencing: results with staphylococcal replicon pC221. EMBO Journal 4, 561-568.

BRÜCKNER, R. \& MATZURA, H. (1985). Regulation of the inducible chloramphenicol acetyltransferase gene of the Staphylococcus aureus plasmid pUB112. EMBO Journal 4, 2295-2300.

BRÜCKNER, R., ZYPRIAN, E. \& MATZURA, H. (1984). 
Expression of a chloramphenicol-resistance determinant carried on hybrid plasmids in Gram-positive and Gram-negative bacteria. Gene 32, 151-160.

Burns, J. L., Mendelman, P. M., Levy, J., Stull, T. \& SMITH, A. L. (1985). A permeability barrier as a mechanism of chloramphenicol resistance in Haemophilus influenzae. Antimicrobial Agents and Chemotherapy 27, 46-54.

Chang, S. \& Cohen, S. N. (1979). High frequency transformation of Bacillus subtilis protoplasts by plasmid DNA. Molecular and General Genetics 168, 111-115.

EICH, K. O. (1985). Handbuch Schweinekrankheiten, 2nd edn. Münster-Hiltrup: Landwirtschaftsverlag $\mathrm{GmbH}$.

Fitton, J. E., Packman, L. C., Harford, S., ZaidenZAIG, Y. \& SHAW, W. V. (1978). Plasmids and the evolution of chloramphenicol resistance. In Microbiology - 1978, pp. 249-252. Edited by D. Schlesinger. Washington DC: American Society for Microbiology.

Gillespie, M. T. \& SkurRay, R. A. (1988). Structural relationships among chloramphenicol-resistance plasmids of Staphylococcus aureus. FEMS Microbiology Letters 51, 205-210.

Gyles, C. L. \& THOEN, C. O. (1986). Pathogenesis of Bacterial Infections in Animals, 1st edn. Ames: Iowa State University Press.

HoRinOUCHI, S. \& WeISBlum, B. (1982). Nucleotide sequence and functional map of $\mathrm{pCl}$ 194, a plasmid that specifies inducible chloramphenicol resistance. Journal of Bacteriology 150, 815-825.

Kloos, W. E., Orban, B. S. \& Walker, D. D. (1981). Plasmid composition of Staphylococcus species. Canadian Journal of Microbiology 27, 271-278.

KRÖGER, M., НOBOM, G., SCHÜtTE, H. \& MAYER, H. (1984). Eight new restriction endonucleases from Herpetosiphon giganteus - divergent evolution in a family of enzymes. Nucleic Acids Research 12, 31273141.

LACEY, R. W. (1980). Rarity of gene transfer between animal and human isolates of Staphylococcus aureus in vitro. Journal of General Microbiology 119, 437-442.

LesLiE, A. G. W., Moody, P. C. E. \& Shaw, W. V. (1988). Structure of chloramphenicol acetyltransferase at $1.75 \AA$ resolution. Proceedings of the National Academy of Sciences of the United States of America 85, 4133-4137.

LyON, B. R. \& SkURRAY, R. (1987). Antimicrobial resistance of Staphylococcus aureus: genetic basis. Microbiological Reviews 51, 88-134.

Maniatis, T., Fritsch, E. F. \& SambroOK, J. (1982). Molecular cloning: a laboratory manual. Cold Spring Harbor, NY: Cold Spring Harbor Laboratory.

Noble, W. C., RahmanN, M. \& Lloyd, D. H. (1988). Plasmids in Staphylococcus hyicus. Journal of Applied Bacteriology 64, 145-149.
Novick, R. P. (1967). Properties of a cryptic high frequency transducing phage in Staphylococcus aureus. Virology 33, 155-166.

Novick, R. (1976). Plasmid-protein relaxation complexes in Staphylococcus aureus. Journal of Bacteriology 127, 1177-1187.

Novick, R. P., Projan, S. J., Rosenblum, W. \& EDELMAN, I. (1984). Staphylococcal plasmid cointegrates are formed by host- and phage-mediated general rec systems that act on short regions of homology. Molecular and General Genetics 195, 374377.

Rolle, M. \& MaYr, A. (1984). Medizinische Mikrobiologie, Infektions- und Seuchenlehre, 5th edn. Stuttgart: Enke-Verlag.

SCHLEIFER, K. H. (1986). Gram-positive cocci. In: Bergey's Manual of Systematic Bacteriology, vol. 2, pp. 999-1035. Edited by P. H. A. Sneath. Baltimore: Williams \& Wilkins.

SchWARZ, ST. \& Blobel, H. (1989). Plasmids and resistance to antimicrobial agents and heavy metals in Staphylococcus hyicus from pigs and cattle. Zentralblatt für Veterinärmedizin, Reihe $B$, (in the Press)

Schwarz, St., Cardoso, M. \& Blobel, H. (1989a). Plasmid encoded resistance to chloramphenicol in 'canine' Staphylococcal intermedius-isolates. Medical Science Research 17, 451-453.

Schwarz, St., Spies, U., Reitz, B., Seyfert, H. M. LÄMMLER, C. \& BlOBEL, H. (1989 $b$ ). Detection and interspecies transformation of a $\beta$-lactamase-encoding plasmid from Pasteurella haemolytica. Zentralblatt für Bakteriologie, Mikrobiologie und Hygiene 1. Abt., Originale A 270, 462-469.

Shaw, W. V. (1967). The enzymatic acetylation of chloramphenicol by extracts of R-factor resistant Escherichia coli. Journal of Biological Chemistry 242, 687-693.

SHAW, W. V. (1975). Chloramphenicol acetyltransferase from chloramphenicol-resistant bacteria. Methods in Enzymology 43, 737-755.

SHAW, W. V. \& BRODSKY, R. F. (1968). Characterization of chloramphenicol acetyltransferase from chloramphenicol-resistant Staphylococcus aureus. Journal of Bacteriology 95, 28-36.

SHAw, W. V. \& UNOWSKY, J. (1968). Mechanism of Rfactor mediated chloramphenicol resistance. Journal of Bacteriology 95, 1976-1978.

Winshell, E. \& SHAW, W. V. (1969). Kinetics of induction and purification of chloramphenicol acetyltransferase from chloramphenicol-resistant Staphylococcus aureus. Journal of Bacteriology 98, 1248-1257.

Zaidenzaig, Y., Fitton, J. E., Packman, L. C. \& SHaW, W. V. (1979). Characterization and comparison of chloramphenicol acetyltransferase variants. European Journal of Biochemistry 100, 609-618. 